\title{
Reduced genetic diversity in endemic Brazilian Lymania spp (Bromeliaceae) populations and implications for conservation
}

\author{
V.C.C. Pamponét ${ }^{1}$, T.F. Alves ${ }^{2}$, R.A. Martinez $^{3}$, R.X. Corrêa ${ }^{1,2}$ and \\ F.A. Gaiotto ${ }^{1,2}$ \\ ${ }^{1}$ Pós-Graduação em Genética e Biologia Molecular, \\ Universidade Estadual de Santa Cruz, Ilhéus, BA, Brasil \\ ${ }^{2}$ Departamento de Ciências Biológicas, Universidade Estadual de Santa Cruz, \\ Ilhéus, BA, Brasil \\ ${ }^{3}$ Departamento de Filosofia e Ciências Humanas, \\ Universidade Estadual de Santa Cruz, Ilhéus, BA, Brasil \\ Corresponding author: F.A. Gaiotto \\ E-mail: gaiotto@uesc.br
}

Genet. Mol. Res. 12 (4): 4352-4362 (2013)

Received September 26, 2012

Accepted February 4, 2013

Published October 10, 2013

DOI http://dx.doi.org/10.4238/2013.October.10.1

\begin{abstract}
We analyzed the genetic diversity of populations of two sympatric species of Lymania (Bromeliaceae), both endemic to the Atlantic rainforest of southern Bahia (Brazil). Lymania azurea has a restricted occurrence, while Lymania smithii has a wider distribution. Our aim was to provide genetic data to contribute to the design of more efficient conservation strategies for these bromeliads, possibly justifying inclusion in the official Brazilian list of Endangered Species. Up to now, L. azurea has been classified by the Brazilian Ministry of the Environment as "data deficient". We sampled four populations of L. azurea throughout its distribution area in southern Bahia and two populations of L. smithii in the same region. Genotyping was performed with 48 random amplified polymorphic DNA markers. Based on the
\end{abstract}


Jaccard genetic similarity index, L. smithii has greater diversity than L. azurea. An analysis of molecular variation showed greater genetic variance within than between populations for both species. $L$. azurea was found to have $20 \%$ inbreeding, probably due to population fragmentation, with $L$. smithii showing only $10 \%$. When we analyzed pairs of populations of $L$. azurea within a conservation unit, we found low population structure $\left(\Phi_{\mathrm{ST}}=0.098\right)$, apparently due to a large degree of gene flow between them. In disturbed areas, we found a higher $\Phi_{\mathrm{ST}}$ $(0.372)$. We found low genetic variability for $L$. azurea, probably as a consequence of habitat fragmentation, supporting the need for its inclusion in the Brazilian list of endangered flora.

Key words: Endangered species; Tropical forest; Genetic structure; Dominant marker; Fragmentation

\section{INTRODUCTION}

Forest fragmentation reduces and isolates populations, favoring inbreeding and genetic drift. The decline in genetic variation limits the evolutionary potential of any species, leading to a risk of extinction (Zucchi et al., 2003). Thus, knowing the genetic diversity is one of the main strategies to support conservation programs, indicating areas and populations with a different level of importance for conservation (Cavallari et al., 2006). Genetic studies are of particular importance within the Atlantic Forest, which today is reduced to less than $12 \%$ of its original cover (Ribeiro et al., 2009).

The physiognomy of the vegetation of many moist Neotropical forests can be characterized by the presence of epiphytic bromeliad species living on the trunks and branches of trees. Due to their rosulated leaves, these plants keep water reservoirs, an important resource for various animals (Scarano et al., 1997; Benzing, 2000; Rocha et al., 2004). Recent studies have suggested that the largest part of the Atlantic Rainforest species occur in a small geographic region (Costa et al., 2012). For example, $47.5 \%$ of the bromeliads from the municipality of Una (Bahia, Brazil) are restricted to southern Bahia and northern Espírito Santo (Fontoura and Santos, 2010) encompassing an area of 6 to 7 square degrees. One species that has strong geographic restriction is Lymania azurea Leme (1987), restricted to three municipalities in southern Bahia, and because of its restriction, Sousa and Wendt (2008) considered it an endangered species, according to World Conservation Union (IUCN) criteria. Thus, the study of genetic diversity is highly suggested to corroborate the definition of the real threat category by the official list.

Lymania smithii Read (1984) has a wider distribution, covering the states of Alagoas, Bahia and Pernambuco (Sousa and Wendt, 2008; Martinelli et al., 2008). Thus, studying both species can provide comparative results to see how populations are structured, evaluating the consequences of environmental impacts on each species. We aimed to assess the genetic diversity of populations of L. azurea and L. smithii for the following reasons: i) to understand the different levels of genetic variability of these sympatric species with significant differences in distribution in the forest; and ii) to generate useful information about the genetic diversity of the species $L$. azurea to define its current conservation status. 


\section{MATERIAL AND METHODS}

\section{Plant material and DNA extraction}

We sampled L. azurea and L. smithii plants found in four natural populations from southern Bahia, Brazil (Table 1 and Figure 1).

\begin{tabular}{|c|c|c|c|c|c|}
\hline \multirow[t]{2}{*}{ Species } & \multirow[t]{2}{*}{ Population name } & \multirow[t]{2}{*}{ Location } & \multicolumn{2}{|c|}{ Geographic coordinates } & \multirow[t]{2}{*}{ No. of plants } \\
\hline & & & Latitude (S) & Longitude (W) & \\
\hline \multirow[t]{4}{*}{ Lymania azurea } & PRCP I & Rebio-Una-BA & $14^{\circ} 11^{\prime} 07^{\prime \prime}$ & $39^{\circ} 03^{\prime} 36^{\prime \prime}$ & 22 \\
\hline & PRCP II & Rebio-Una-BA & $15^{\circ} 11^{\prime} 01^{\prime \prime}$ & $39^{\circ} 04^{\prime} 01^{\prime \prime}$ & 29 \\
\hline & Piedade & Rebio-Una-BA & $15^{\circ} 10^{\prime} 21^{\prime \prime}$ & $39^{\circ} 09^{\prime} 58^{\prime \prime}$ & 33 \\
\hline & Sapucaeira & Ilhéus-BA & $14^{\circ} 58^{\prime} 15^{\prime \prime}$ & $39^{\circ} 07^{\prime} 84^{\prime \prime}$ & 17 \\
\hline \multirow{2}{*}{ Lymania smithii } & PRCP I & Rebio-Una-BA & $14^{\circ} 11^{\prime} 47^{\prime \prime}$ & $39^{\circ} 03^{\prime} 36^{\prime \prime}$ & 17 \\
\hline & PRCP II & Rebio-Una-BA & $15^{\circ} 11^{\prime} 01^{\prime \prime}$ & $39^{\circ} 04^{\prime} 01^{\prime \prime}$ & 17 \\
\hline
\end{tabular}

*Rebio-Una-BA (Biological Reserve, Una-Bahia-Brasil).

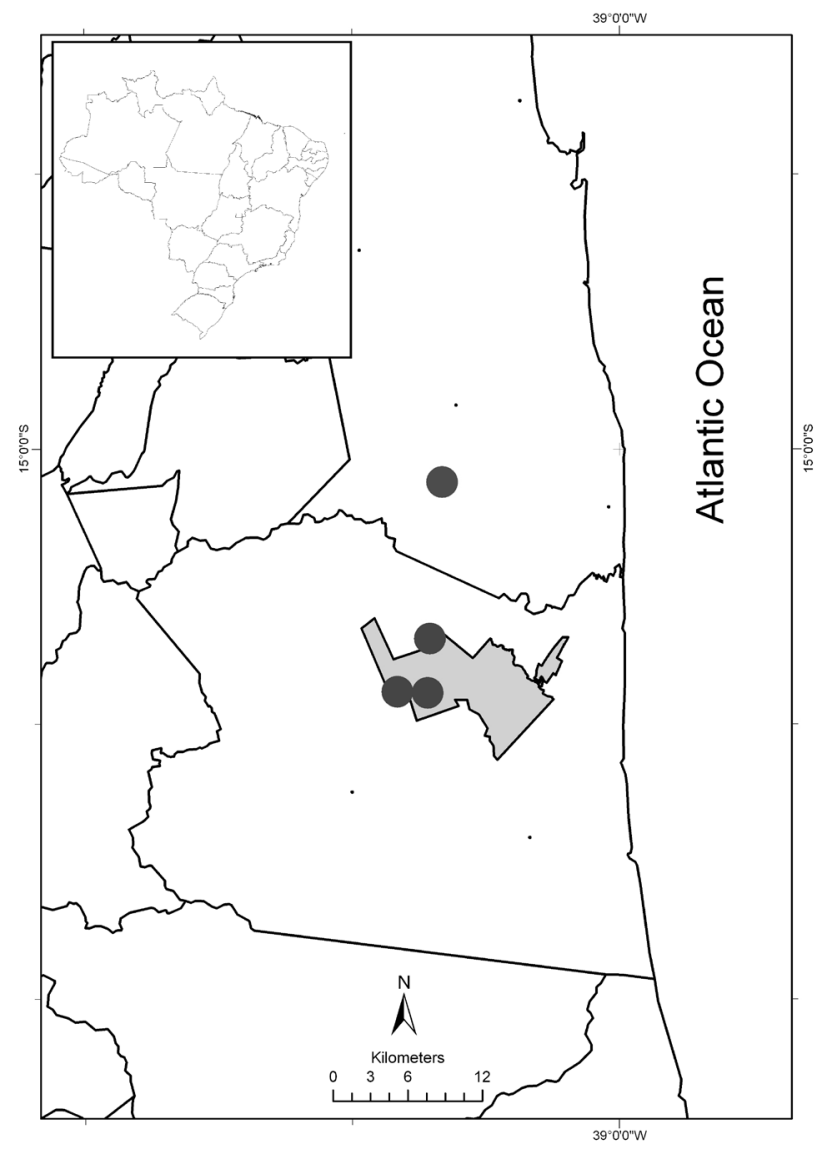

Figure 1. Map showing the location of the sampled population of Lymania. 
Populations PRCP I (Príncipe I) and Piedade occur within the Rebio-Una (Reserva Biológica de Una, Bahia, Brazil), within a continuous forest fragment PRCP II (Príncipe II), which is in a border area of the reserve, vulnerable to anthropic action. Rebio-Una is a unit of strictly protected areas declared part of the Biosphere Reserve of the Atlantic Forest in southern Bahia. The Sapucaeira population, Ilhéus (Bahia), occurs in discontinuous anthropized fragments of the Atlantic Forest.

Genomic DNA was extracted using 2\% CTAB according to Doyle and Doyle (1990).

\section{Screening of primers and RAPD amplification conditions}

A total of 143 RAPD primers from Operon Technologies were tested, selecting 13 as optimal for analyses (Table 2). Primers were selected according to the amount and quality of polymorphic amplified bands.

Table 2. RAPD primers used for Lymania azurea and Lymania smithii. Total number of amplified bands, number of monomorphic and polymorphic bands per primers, and range of selected molecular markers.

\begin{tabular}{lccccc}
\hline Specie & Primer & Total & Monomorphic bands & Polymorphic bands & Range (bp) \\
\hline Lymania azurea & OPA-02 & 11 & 0 & 05 & $400-1500$ \\
& OPA-12 & 12 & 0 & 05 & $300-1480$ \\
& OPF-13 & 09 & 1 & 05 & $450-1000$ \\
& OPJ-11 & 07 & 0 & 05 & $400-1450$ \\
& OPP-01 & 12 & 1 & 06 & $300-1500$ \\
& OPP-04 & 09 & 1 & 04 & $300-1000$ \\
& OPP-13 & 09 & 1 & 03 & $800-1480$ \\
& OPP-14 & 11 & 0 & 04 & $200-900$ \\
& OPV-15 & 12 & 1 & 05 & $400-1500$ \\
& OPW-12 & 09 & 0 & 06 & $460-1500$ \\
& OPA-02 & 11 & 2 & 3 & $300-1500$ \\
& OPA-08 & 05 & 0 & 2 & $300-1480$ \\
& OPA-12 & 10 & 2 & 4 & $450-1000$ \\
& OPF-13 & 08 & 2 & 5 & $550-1500$ \\
& OPG-18 & 12 & 2 & 3 & $400-1450$ \\
& OPJ-11 & 10 & 0 & 5 & $300-1500$ \\
& OPP-01 & 10 & 1 & 6 & $300-1000$ \\
& OPP-04 & 10 & 2 & 4 & $400-600$ \\
& OPP-12 & 12 & 1 & 3 & $800-1480$ \\
& OPP-13 & 14 & 2 & 3 & $200-900$ \\
& OPP-14 & 13 & 1 & 6 & $250-1500$ \\
\hline
\end{tabular}

Several experiments were performed to optimize the amplification protocol, according to Ramos et al. (2008). These were (a) testing different concentrations of DNA $(7.5,15$, 30,60 and $100 \mathrm{ng}$ ), to avoid polymerase chain reaction (PCR) artifacts caused by excess or lack of DNA and (b) evaluation of RAPD reproducibility by repeating PCR on alternate days to select markers that were always detected. During the experiments, reagent concentrations, annealing temperature and the thermal cycler remained unchanged.

RAPD reactions were prepared in a volume of $13 \mu \mathrm{L}$ containing: $1 \mathrm{U}$ Taq DNA polymerase, $7.5 \mathrm{ng}$ DNA template, $2.12 \mu \mathrm{M}$ each primer , $0.2 \mathrm{mM}$ dNTPs, $0.09 \mathrm{mM} \mathrm{MgCl}, 10 \mathrm{X} 2$ $\mathrm{mM}\left(\mathrm{NH}_{4}\right)_{2} \mathrm{SO}_{4}$ reaction buffer, $0.8 \mathrm{mg} / \mu \mathrm{L}$ bovine serum albumin and Milli-Q ultrapure water added to complete the volume. The negative control had sterile Milli-Q water instead of DNA.

PCR was performed using the GeneAmp ${ }^{\circledR}$ PCR System 9700 (PerkinElmer), under 
the following cycling conditions: $1 \mathrm{~min}$ at $92^{\circ} \mathrm{C}$, followed by 40 cycles of $92^{\circ} \mathrm{C}$ for $1 \mathrm{~min}$, $35^{\circ} \mathrm{C}$ for $1 \mathrm{~min}$, and $72^{\circ} \mathrm{C}$ for $2 \mathrm{~min}$, with a final 5 -min extension at $72^{\circ} \mathrm{C}$. PCR products were separated by electrophoresis on $1.5 \%$ agarose gels with ethidium bromide staining, run in $1 \mathrm{X}$ TBE (0.89 M Tris, $0.89 \mathrm{M}$ boric acid, 0.11 $\mathrm{M} \mathrm{Na}_{2}$ EDTA, $\mathrm{pH} 8.3$ ) buffer with a 1-Kb ladder (Fermentas Life Sciences). Images were captured using a UV light system.

\section{Data analysis}

A genetic similarity matrix of presence (1) or absence ( 0 ) of marker bands was generated with NTSYS 2.1 (Rohlf, 2000). The Jaccard (1901) similarity matrix was used to estimate the dendrogram topology which was performed by UPGMA (unweighted pair group method with arithmetical means) using pairs of samples. We calculated the Mantel cophenetic correlation (r) between the genetic similarity matrix and dendrogram, estimated on 10,000 permutations.

Analysis of molecular variance was performed using AMOVA-PREP (Miller, 1998) and AMOVA 1.55 (Excoffier et al., 1992). Huff et al. (1993) distance matrix was used to perform the analysis of variance for estimating the $\Phi_{\mathrm{ST}}$ parameter. Thus, we evaluated the molecular partition of genetic variance within and between populations for each species.

\section{RESULTS}

\section{Genetic diversity and population genetic structure}

\section{L. azurea}

According to the Jaccard similarity index, variation ranged between 0.2 and 1.0 among all samples, detecting genetically distinct groups, within and between populations (Figure 2). Populations from the Rebio-Una (PCRP I and Piedade) showed a better distribution of genetic variability. PCRP II and Sapucaeira had a genetic distance around 40\% (Figure 2).

The Mantel test between genetic similarity matrix and its corresponding cophenetic correlation matrix (r) was 0.878 .

AMOVA results highlighted a high genetic structure among populations $(\mathrm{P}<0.001)$. Of the total genetic variance, $20.53 \%$ was due to differences between populations, while $79.48 \%$ were attributed to differences between individuals within populations, demonstrating strong structuring among these populations. The $\Phi_{\mathrm{ST}}$ estimated for this species was 0.20 (Table 3).

The analyses of pairs of populations also detected a genetic structure (Table 4). Populations within the protected area (PRCP I and Piedade) showed a less pronounced structure $\left(\Phi_{\mathrm{ST}}=0.098\right)$ when compared with the populations that border populations PCRP II and Sapucaeira $\left(\Phi_{\mathrm{ST}}=0.372\right)$.

\section{L. smithii}

The Jaccard similarity index estimated for pairs of $L$. smithii individuals varied between 0.4 and 1.0, detecting some genetically distinct groups, within and between populations (Figure 3). For L. smithii, the estimated value of the Mantel cophenetic correlation (r) between genetic similarity matrix and dendrogram was 0.689 . AMOVA (Table 5) indicated that the ge- 
netic diversity was highly significant $(\mathrm{P}<0.001)$ within and between populations. Of the total genetic molecular variance, $10.02 \%$ was due to interpopulation differences, while $89.98 \%$ was attributed to differences within populations, with $F_{\mathrm{ST}}=0.1$.

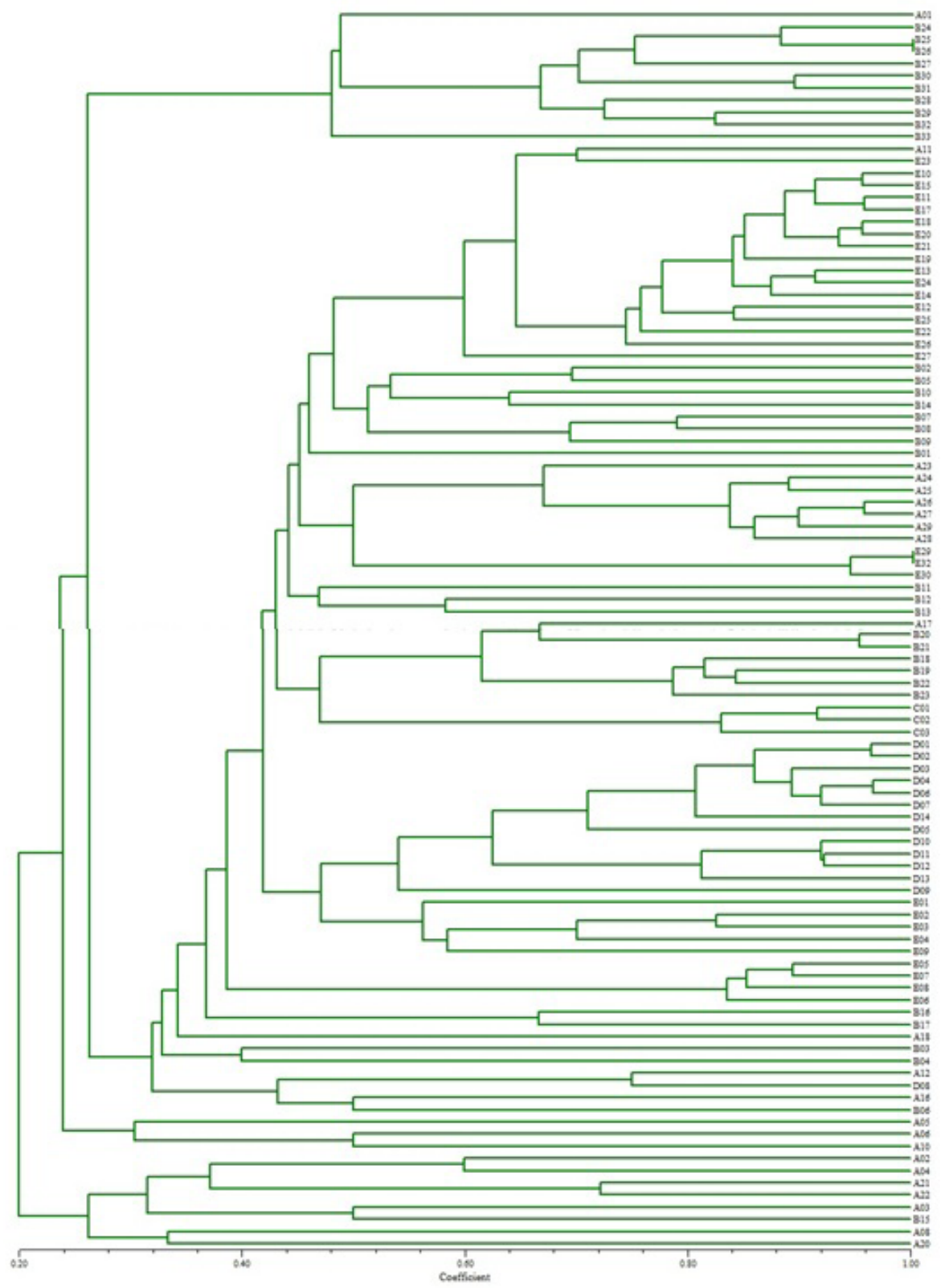

Figure 2. Genetic similarity among four populations of Lymania azurea, defined by UPGMA clustering method based on Jaccard index. Populations sampled were represented by: A. PRCP I; B. Piedade; C. e D. Sapucaeira, and E. PRCP II. 
Table 3. Analysis of molecular variance (AMOVA) based on four populations Lymania azurea.

\begin{tabular}{|c|c|c|c|c|c|}
\hline Sources of variation & d.f. & SS & $\%$ of change & $\mathrm{P}$ & Statistics $F_{\mathrm{ST}}$ \\
\hline Within populations & 3 & 185.757 & 20.53 & $\mathrm{P}<0.001 * *$ & 0.20 \\
\hline Between population & 98 & 813.155 & 79.47 & $\mathrm{P}<0.001 * *$ & $1-F_{\mathrm{ST}}=0.80$ \\
\hline Total & 101 & 998.912 & 100.00 & & 1 \\
\hline
\end{tabular}

**highly significant.

\begin{tabular}{|c|c|c|c|c|}
\hline Statistics $F_{\mathrm{ST}}$ & PRCP I & PRCP II & Piedade & Sapucaeira \\
\hline PRCP I & - & - & - & - \\
\hline PRCP II & 0.274 & - & - & - \\
\hline Piedade & 0.098 & 0.190 & - & - \\
\hline Sapucaeira & 0.326 & 0.372 & 0.244 & - \\
\hline
\end{tabular}

$\mathrm{P}<0,001$.

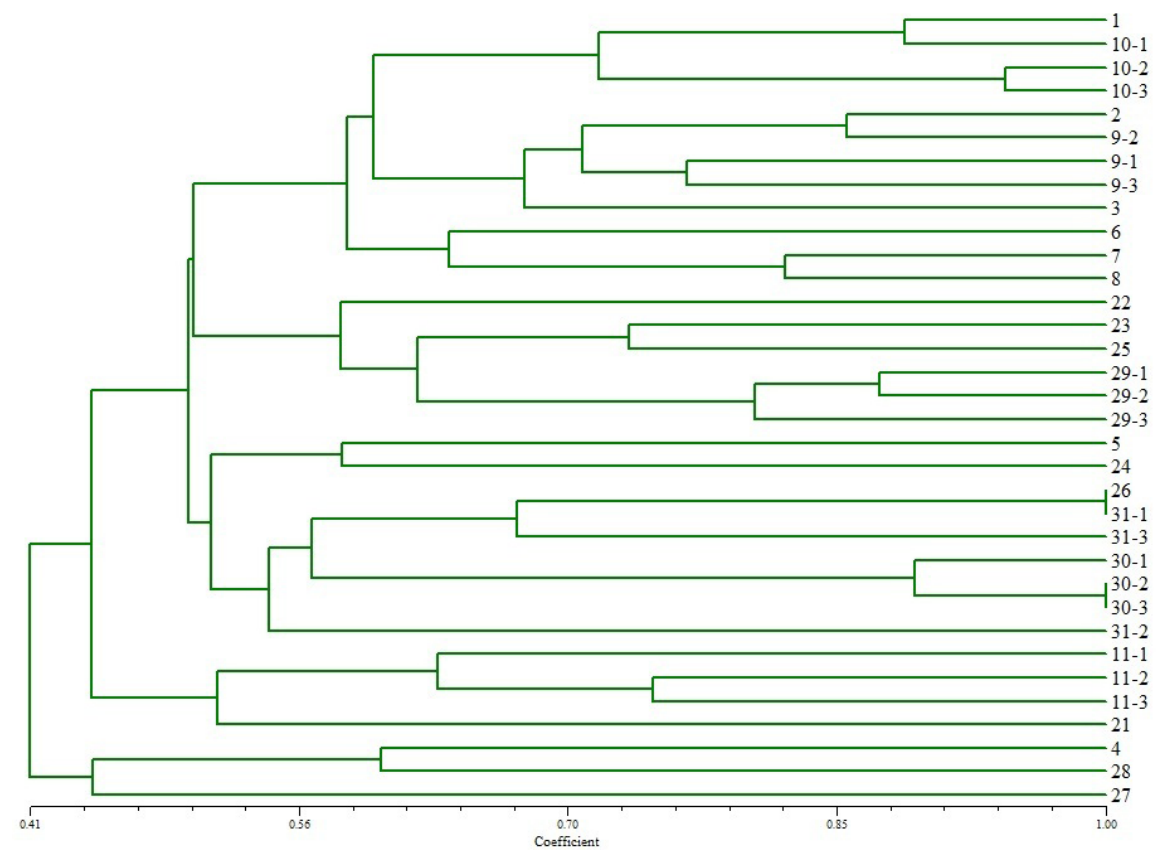

Figure 3. Dendrogram of genetic similarity in Lymania smithii defined by UPGMA clustering method based on Jaccard genetic similarities. The individuals of the populations analyzed were: PRCP I (1 to 11-3) and PRCP II (22 to 31-3).

\begin{tabular}{|c|c|c|c|c|c|}
\hline Sources of variation & d.f. & SS & $\%$ of change & $\mathrm{P}$ & Statistic $F_{\mathrm{ST}}$ \\
\hline Within populations & 1 & 16.412 & 10.02 & $\mathrm{P}<0.001 * *$ & 0.1 \\
\hline Between population & 32 & 181.529 & 89.98 & $\mathrm{P}<0.001 * *$ & $1-F_{\mathrm{ST}}=0.9$ \\
\hline Total & 33 & 197.941 & 100.00 & & 1 \\
\hline
\end{tabular}




\section{DISCUSSION}

This study helped to understand the impacts of fragmentation on populations of two Lymania species through quantified intraspecific genetic diversity. Intense anthropic activity seems to lead to a troublesome genetic structure for $L$. azurea, probably as a consequence of limited gene flow between forest fragments.

The dominant character of RAPD markers has been criticized (Lacerda et al., 2002), as well as their tendency to have low levels of repeatability (Jones et al., 1997; Ferreira and Grattapaglia, 1998; Pérez et al., 1998). However, there are laboratory procedures that ensure the reproducibility of RAPD data (Fraga et al., 2005; Atienzar and Jha, 2006; Ramos et al., 2008). We standardized all our protocols in detail so that that other researchers could reproduce our results with Lymania sp. Reproducibility problems of RAPD markers could be due to the use of primers that amplify mismatch bands and not necessarily to the technique itself (Ramos et al., 2008). Although other more precise molecular markers are available, RAPDs still offer the quickest and least expensive solution to obtaining preliminary genetic data, besides requiring very small quantities of DNA, an important point in studying species with restricted occurrence.

A better status of genetic diversity for populations in protected areas is probably the result of forest connectivity, allowing some gene flow. Corridors of original forest can improve landscape diversity among fragments, increasing functional connections, such as the maintenance of gene flow (Bittencourt and Sebbenn, 2007).

The Rebio-Una has one of the largest portions of continuous Atlantic Forest in northeastern Brazil, regarded as a priority area for conservation because of its high endemism rates for various biological groups (Paciencia and Prado, 2004).

Little is known about the reproductive biology of Lymania, but similar patterns of genetic structure and concern have been reported for other species of bromeliads. Cavallari et al. (2006) observed significant genetic differences among groups of three species of Encholirium (Bromeliaceae). This may be due to the low viability of its seeds, for they are not dispersed by animals or the wind. Molecular structure among L. azurea populations could be due to limited gene flow caused by anthropic landscape fragmentation. The value of the genetic structure for $L$. azurea was more than twice that observed for $L$. smithii, indicating a strong genetic structure within the genus, particularly when comparing sympatric species.

There seems to be no difference between congeners under different conservation status, rare and generalized in terms of division of genetic variation within and between populations (Gitzendanner and Soltis, 2000). This helps to understand historical causes of rarity and commonness and how they affect population genetics. We find no biological reason to explain restricted distribution of L. azurea. Since it is so similar to L. smithii in ecological and morphological terms, there is apparently no external parameters to support the significant differences in terms of area of distribution. However, some hypotheses can be considered: i) they may have different pollinators, even considering the few morphological differences in flowers; ii) $L$. azurea could be the result of a speciation process. The historical distribution of L. smithii apparently has persisted until the present. As L. azurea had a more recent origin, it had no time to expand its distribution. However, landscape fragmentation is currently limiting its distribution expansion. To test this hypothesis, studies with other molecular tools and a phylogeographical approach should be conducted. 
Research with three species of Encholirium (Bromeliaceae) found that the species most amply distributed, with more populations and a larger number of individuals, showed the highest molecular genetic diversity, and that restricted and endangered species had low genetic diversity (Cavallari et al., 2006). For Astragalus (Fabaceae), lower levels of genetic diversity are found in species with a restricted distribution (Karron et al., 1988).

\section{Implications for conservation}

It is important to understand the fundamental differences between nature conservation and conservation genetics (Frankel and Soule, 1981). Nature conservation is designed to protect areas that represent habitats and communities that can be identified. The genetic conservation goes beyond, as it is concerned with genetic differences within those protected areas. Thus, allying the study of genetic consequences of forest fragmentation with the design of conservation strategies should be a priority in any country's environmental agenda.

The loss of genetic diversity (genetic erosion) and extinction of species should be strictly addressed by the maintenance of gene flow and the development of strategies to prevent biodiversity loss. Small fragments can promote a network connection for a significant number of species, thus maintaining genetic diversity (Turner and Corlett, 1996). Habitat fragmentation may also affect the abundance and diversity of plant pollinators.

The high degree of genetic structure in L. azurea indicates that all free ranging individuals are vital for maintenance of current genetic diversity. Thus, removal of plants from the populations must be done exclusively for ex situ conservation purposes or to maintain the representation of this important genetic resource.

Other bromeliads have shown high rates of seed germination Cavallari et al. (2006). Thus, for ex situ conservation by germplasm bank, it is preferable to remove only the seeds from populations. However, for Lymania some specific studies are needed to estimate the number of necessary seeds to maintain its natural genetic variability.

When planning in situ conservation actions, species must be allowed certain rates of natural selection and evolution within their natural environments. However, economic and political interests that influence the decision-making and the definition of conservation areas pose one of the biggest challenges for in situ conservation.

The strong structure found for L. azurea $\left(F_{\mathrm{ST}}=0.20\right)$ indicates the urgency of conservation measures. Our results suggest that forest corridors in southern Bahia should be supplemented with this species, restoring the natural genetic variability of $L$. azurea in southern

Bahia. Corridors act as connectivity restorers, thus gene flow promoters. Finally, it should be understood that before forest management, it is essential to have a level of knowledge of the reproductive biology and genetic structure of the species to be managed (Hall et al., 1996). Now, some decision and conservation strategies can be guided by genetic diversity estimated in this study, which may also help in the official inclusion of this species in the Brazilian list of endangered species Brazilian Institute of Environment and Renewable Natural Resources (IBAMA) and also on the list of the International Union for Conservation of Nature (IUCN).

\section{CONCLUSIONS}

Our study provided technical knowledge about the genetic status of populations of $L$. 
azurea and $L$. smithii. It was possible to diagnose that both species have reduced genetic diversity. However, processes of genetic drift and habitat loss in L. azurea have led to critical levels of genetic structure. Thus, we recommend urgency in conservation measures and inclusion of L. azurea on the list of endangered Brazilian flora species.

\section{ACKNOWLEDGMENTS}

Research supported by Fundação Biodiversitas (\#0138F/012005). V.C.C. Pamponét received a master's fellowship from Fundação de Amparo à Pesquisa do Estado da Bahia (FAPESB); R.X. Corrêa and F.A. Gaiotto have research fellowships from the National Council for Scientific and Technological Development (CNPq).

\section{REFERENCES}

Atienzar FA and Jha AN (2006). The random amplified polymorphic DNA (RAPD) assay and related techniques applied to genotoxicity and carcinogenesis studies: a critical review. Mutat. Res. 613: 76-102.

Benzing DH (2000). Bromeliaceae: Profile of an Adaptive Radiation. Cambridge University Press, New York.

Bittencourt JMV and Sebbenn AM (2007). Patterns of pollen and seed dispersal in a small, fragmented population of the wind-pollinated tree Araucaria angustifolia in southern Brazil. Heredity 99: 580-591.

Cavallari MM, Forzza RC, Veasey EA, Zucchi MI, et al. (2006). Genetic variation in three endangered species of Encholirium (Bromeliaceae) from Cadeia do Espinhaço, Brazil, detected using RAPD markers. Biodivers. Conserv. 15: 4357-4373

Costa A, Fontoura T and Amorim AM (2012). Novelties in Bromeliaceae from the northeastern Atlantic Rainforest in Brazil. J. Torrey Bot. Soc. 139: 35-45.

Doyle JJ and Doyle JL (1990). Isolation of plant DNA from fresh tissues. Focus 12: 13-15.

Excoffier L, Smouse PE and Quattro JM (1992). Analysis of molecular variance inferred from metric distances among DNA haplotypes - application to human mitochondrial DNA restriction data. Genetics 131: 479-491.

Ferreira ME and Grattapaglia D (1998). Introdução ao Uso de Marcadores Moleculares em Análise Genética, 3nd edn. EMBRAPA-CENARGEM, Brasília, DF.

Fontoura T and Santos FAM (2010). Geographic distribution of epiphytic bromeliads in the Una region, northeastern Brazil. Biota Neopropica 10: 127-132.

Fraga J, Rodriguez J, Fuentes O, Fernandez-Calienes A, et al. (2005). Optimization of random amplified polymorphic DNA techniques for use in genetic studies of Cuban triatominae. Rev. Inst. Med. Trop. São Paulo 47: 295-300.

Frankel OH and Soule ME (1981). Conservation and Evolution. Cambridge University Press, Cambridge.

Gitzendanner MA and Soltis PS (2000). Patterns of genetic variation in rare and widespread congeners. Ame. J. Bot. 87: 783-792.

Hall P, Walker S and Bawa K (1996). Effects of forest fragmentation on genetic diversity and mating system in a tropical tree, Pithecellobium elegans. Conserv. Biol. 10: 757-768.

Huff DR, Peakall R and Smouse PE (1993). RAPD variation within and among natural populations of outcrossing buffalograss. Theor. Appl. Gene 86: 927-934.

Jaccard P (1901). Etude comparative de la distribuition florale dans une porion des Alpes et des Jura. Bull. Soc. Vandoise Sci. Nat. 37: 547-579.

Jones CJ, Edwards KJ, Castaglione S, Winfield MO, et al. (1997). Reproducibility testing of RAPD, AFLP and SSR markers in plants by a network of European laboratories. Mol. Breed. 3: 381-390.

Karron JD, Linhart YB, Chaulk CA and Robertson CA (1988). Genetic structure of populations of geographically restricted and widespread species of Astragalus (Fabaceae). Am. J. Bot. 75: 1114-1119.

Lacerda DR, Acedo MDP, Filho JPL and Lovato MB (2002). A técnica de RAPD: uma ferramenta molecular em estudos de conservação de plantas. Lundiana 3: 87-92.

Leme EMC (1987). Novas Bromeliáceas Nativas no Brasil. Bradea 4: 392-404.

Martinelli G, Vieira CM, Gonzalez M, Leitman P, et al. (2008). Bromeliaceae da Mata Atlântica brasileira: lista de espécies, distribuição e conservação. Rodriguésia 59: 209-258.

Miller MP (1998). Amova-Prep 1.01: A Program for the Preparation of AMOVA Input Files From Dominant-Marker Raw Data. Department of Biological Sciences, Northern Arizona University, Arizona, USA. 
Paciencia MLB and Prado J (2004). Efeitos de borda sobre a comunidade de pteridófitas na Mata Atlântica da região de Una, sul da Bahia. Bras. Revi. Bras.. Bot. 27: 641-653.

Pérez T, Albornoz J and Domínguez A (1998). An evaluation of RAPD fragment reproducibility and nature. Mol. Ecol. 7: 1347-1357.

Ramos JR, Telles MP, Diniz-Filho JA, Soares TN, et al. (2008). Optimizing reproducibility evaluation for random amplified polymorphic DNA markers. Genet. Mol. Res. 7: 1384-1391.

Read RW (1984). The "Evolution" of a new genus Lymania gen. nov. J. Bromeliad Soc. 34: 199-216.

Ribeiro MC, Metzger JP, Martensen AC, Ponzoni FJ, et al. (2009). The Brazilian Atlantic Forest: how much is left, and how is the remaining forest distributed: implications for conservation. Biol. Conserv. 142: 1144-1156.

Rocha CFD, Nunes-Freitas AF, Cogliatti-Carvalho L and Rocha-Pessôa TC (2004). Habitat disturbance in the Brazilian coastal sand dune vegetation and related richness and diversity of bromeliad species. Vidália 2: 52-72.

Rohlf FJ (2000). NTSYS-pc: Numerical Taxonomy and Multivariate Analysis System. Version 2.1. Exeter Software, Setauket, NY.

Scarano FR, Ribeiro KT, Moraes LFD and Lima HC (1997). Plant establishment on flooded and unflooded patches of a freshwater swamp forest in southeastern Brazil. J. Trop. Ecol.793-803.

Sousa LOF and Wendt T (2008). Taxonomy and conservation of the genus Lymania (Bromeliaceae) in the southern Bahian Atlantic Forest of Brazil. Bot. J. Linn. Soc. 157: 47-66.

Turner IM and Corlett T (1996). The conservation value of small, isolated fragments of lowland tropical rain forest. Trends Ecol. Evol. 11: 330-333.

Zucchi MI, Brondani RV, Pinheiro JB, Coelho ASG, et al. (2003). Genetic structure and gene flow in Eugenia dysenterica DC in the Brazilian Cerrado utilizing SSR markers. Gene. Mol. Biol. 449-458. 